\title{
QuEChERS-HPLC-DAD method for sulphonamides in chicken breast
}

\author{
Simone Caetani Machado ${ }^{1}$, Mariane Landin-Silva ${ }^{1}$, Patrícia Penido Maia $^{1}$, \\ Susanne Rath ${ }^{2}$, Isarita Martins ${ }^{1, *}$
}

\author{
${ }^{1}$ Laboratório de Análises de Toxicantes e Fármacos, Faculdade de Ciências Farmacêuticas, Universidade Federal de Alfenas \\ ,'Instituto de Química, Departamento de Química Analítica, Universidade de Campinas
}

\begin{abstract}
The development of a QuEChERS-HPLC-DAD method using a Lichrospher 60 RP-Select B column (250 x $4.6 \mathrm{~mm} \times 5 \mu \mathrm{m})$ at $40^{\circ} \mathrm{C}$, mobile phase constituted by phosphate buffer:acetonitrile $(75: 25, \mathrm{v} / \mathrm{v})$ at a initial flow rate of $0.5 \mathrm{~mL} \mathrm{~min}^{-1}$, increased by $1.2 \mathrm{~mL} \mathrm{~min}^{-1}$ and at $265 \mathrm{~nm}$ is presented for simultaneous determination of sulphadiazine, sulphametoxipiridazine and sulphamethoxazole in chicken breast samples. QuEchERS is inexpensive, fast and easy, and the extraction of the analytes of the matrix was successfully employed. In addition, the method presented linearity, in the range of 25, 50, 100, 150, 175, and $200 \mu \mathrm{g} \mathrm{kg}^{-1}$, precision, selectivity and sensitivity. The intraday precision (RSD \%) for QuEChERS method was between 3.6-10.8 (SDZ), 6.9-14.1 (SPZ) and 1.9-10.9 (SMX) and interday precision (RSD\%) was between 1.5-9.7, 1.7-4.1 and 2.1-10.2, respectively. Results of accuracy (bias) were in the range of -8.6 to $+11.9 \%$. Therefore, the validated method is clearly useful for the practical residue monitoring of the drugs evaluated in chicken samples, as all the values were within the acceptable criteria used for food safety. Of 6 samples analyzed, none of them showed contamination of the sulphonamides studied at detectable levels.
\end{abstract}

Uniterms: QuEChERS. Sulphonamides determination. Veterinary drugs residues. Chicken breast. HPLC-DAD

O desenvolvimento de um método QuEChERS-HPLC-DAD usando uma coluna Lichrospher RP-60 Select B $(250 \times 4,6 \mathrm{~mm}$ x $5 \mu \mathrm{m})$ a $40{ }^{\circ} \mathrm{C}$, fase móvel constituída por tampão de fosfato: acetonitrila $\left(75: 25\right.$, v/v) a uma vazão inicial de $0,5 \mathrm{~mL} \mathrm{~min}^{-1}$, aumentando $1,2 \mathrm{~mL} \mathrm{~min}^{-1}$ e a $265 \mathrm{~nm}$ é apresentado para a determinação simultânea de sulfadiazina, sulfametoxipiridazina e sulfametoxazol em amostras de peito de frango. O QuEChERS é barato, rápido e fácil, e a extração dos analitos da matriz foi empregada com sucesso. Além disso, o método apresentou linearidade, na faixa de 25, 50, 100, 150, 175 e $200 \mu \mathrm{g} \mathrm{kg}^{-1}$, precisão, seletividade e sensibilidade. A precisão intradia (RSD \%) para o método QuEChERS foi entre 3,6-10,8 (SDZ), 6,9-14,1 (SPZ) e 1,9-10,9 (SMX) e a precisão interdias (RSD\%) foi entre 1,5-9,7, 1,7-4,1 e 2,1-10,1, respectivamente. Resultados de exatidão (tendenciosidade) foram na faixa de $-8,6$ a $+11,9 \%$. Portanto, o método validado é útil para a monitorização de resíduos de medicamentos avaliados em amostras de frangos, bem como todos os valores estavam dentro dos critérios aceitáveis utilizados para a segurança dos alimentos. De seis amostras analisadas, nenhuma apresentou contaminação de sulfonamidas nos níveis detectáveis estudados.

Unitermos: QuEChERS. Determinação de sulfonamidas. Resíduos de medicamentos veterinários. Peito de frango. HPLC-DAD

\footnotetext{
*Correspondence: I. Martins. Laboratório de Análises de Toxicantes e Fármacos, Faculdade de Ciências Farmacêuticas, Universidade Federal de Alfenas. Rua Gabriel Monteiro da Silva, 700, 37130.000 - Alfenas - MG, Brasil. Telefone: 55-35-3299-1342. Fax: 55-35-3299-1067. E-mail: isarita@unifal-mg.edu.br; isaritams@gmail.com
} 


\section{INTRODUCTION}

Sulphonamides (SAs) are antimicrobial agents most commonly used in veterinary practice to treat diseases, to control and prevent infection and to promote growth and production efficiency; they are inexpensive and offer a wide spectrum of antimicrobial activity (Biswas et al., 2007; Mamani, Reyes, Rath, 2009). The inappropriate or excessive use of these drugs can result in the presence of drug residue in animal tissue, which contributes to the generation of long-term health effects, including microbial antibiotic resistance, and can cause potential adverse side effects in hypersensitive individuals (Chiaochan et al., 2010). Thus, many efforts, such as monitoring veterinary drug residues to ensure the safety of food, have been made to protect consumers' health.

To limit human exposure, the European Union (EU) has set maximum residue limits (MRLs) for different food contaminants in a certain number of raw foods on the basis of toxicological data, acceptable daily intake values and the performance of current analytical technology. Within the EU, one of the main documents stating the MRLs of authorized veterinary drugs in food of animal origin is Council Regulation 2377/90/EC, which was repealed by Commission Regulation 470/2009 of the European Parliament and the Council (European Commission, 2009a). The pharmacologically active substances that have an MRL (permitted) are contained in Regulation 37/2010 of the Council, which provides an MRL of $100 \mu \mathrm{g} \mathrm{kg}^{-1}$ for SAs in foods of animal origin, stating that the combined total residues of all substances within the sulfonamide group should not exceed this MRL value (European Commission, 2009b). In Brazil, these limits are established in the Normative Instruction 14, dated May 25, 2009, from the Ministério da Agricultura, Pecuária e Abastecimento (MAPA, 2009).

Therefore, it is necessary to develop sensitive and easy analytical methods that can be used routinely, comply with current legislation and allow for the determination of residues of veterinary drugs in food of animal origin, thus ensuring the safety of the supplied products.

In 2002, the European Union (EU) issued a specific regulation decision (2002/657/EC) concerning the performance of methods and the interpretation of results in the official control of residues in products of animal origin. It was mandatory that some new parameters must be calculated, such as the limit of decision ( $\mathrm{CC} \alpha)$ and detection capability (CC $\beta$ ) (European Commission, 2002).

For detecting antimicrobial residues in food, bioassay techniques are widely used in screening methods because of their simplicity and low cost (Knecht et al., 2004; Lamar, Petz, 2007). However, before samples are condemned for containing levels of antimicrobials exceeding the stipulated levels, it is well recognized that these methods must be supported by sufficiently selective and sensitive chemical methods (Bogialli, Di Corsia, 2009). The low selectivity at the detection step created a need for highly selective sample preparation that often included lengthy extractions and clean-up procedures.

Animal tissues are known to be rich in protein components (US Department of Agriculture, 2009), which can bind to antibiotics, especially polar compounds. Therefore, an appropriate sample treatment is essential for obtaining reliable results in antibiotic analyses. Organic solvents, such as acetonitrile, methanol, and ethanol, are commonly employed in the precipitation of proteins in biological matrices. Acetonitrile typically provides high extraction efficiency and often minimizes co-extraction of lipids from animal tissues (Chiaochan et al., 2010).

Several extraction methods have been used for SA-residue analysis; however, most are long and tedious, involving liquid-liquid extraction (LLE) (Haller et al., 2002; Chico et al., 2008), or solid-phase extraction (SPE) (Pecorelli et al., 2004; Koesukwiwat, Jayanta, Leepipatpiboon, 2007; Bedor et al., 2008), which also include an additional step to precipitate the proteins. In many instances, LLE and SPE were used in combination; for example, after deproteinization/analyte extraction by means of a suitable organic solvent and solvent removal, the extracts were subsequently purified using suitable SPE procedures (Biswas et al., 2007; Soto-Chinchilla, García-Campaña, Gamiz-Gracia, 2007; Gamba et al., 2009). Procedures based on matrix solid-phase dispersion have been proposed to simplify the extraction step (Kishida, Furusawa, 2001; Bogialli et al., 2003; Posyniak, Zmudzki, Mitrowska, 2005). Solid-phase microextraction (SPME) has been used for the determination of SAs in meat (Lu, Chen, Lee, 2007).

A significant step forward in reducing the time to process a sample was described in 2003: the QUick, Easy, CHeap, Effective, Rugged and Safe (QuEChERS) method by Anastassiades et al. (2003) for pesticide analysis. The greater diversity in the chemical properties of veterinary drugs, compared to pesticides, has made combining them into large analytical suites difficult; however, this method has been used successfully by some researchers and is always accompanied by detection based on mass spectrometry (Stubbings, Bigwood, 2009; Frenich et al., 2010). Currently, there are no reports in the literature of the analysis of SAs using the QuEChERS method and liquid chromatography with a photodiode array detector. The method is based on an acetonitrile extraction/partitioning of the contaminants and water, and proteins are removed from the sample by salting out with sodium chloride and magnesium sulphate, 
followed by a dispersive-SPE clean-up, which requires the addition of small amounts of bulk SPE packing sorbents to the extracts (Anastassiades et al., 2003).

Separation techniques, such as high-performance liquid chromatography (LC) (Tsai et al., 2010) and capillary electrophoresis (Kowalski et al., 2011; Chu et al., 2009), have been widely used to analyze SAs in food samples. These techniques require elaborate sample preparation procedures before quantitation to eliminate interferences from the food matrix and to concentrate the analyte. The extent of the sample preparation depends on the detection device of the chromatographic system in which the detection systems commonly used can be more or less selective and sensitive. LC has been the most frequently used instrumental technique coupled with UV, photodiode array detection (Christodoulou, Samanidou, Papadoyannis, 2007; García-Mayor et al., 2006), fluorimetric detection (Costi, Sicilia, Rubio, 2010) and mass spectrometry (Sheridan et al., 2008).

The aim of the work was to develop and validate a method for the determination of three SAs (sulphadiazine, sulphamethoxypyridazine and sulphamethoxazole) in chicken breast. The method involves an easy extraction technique based on the QuEChERS procedure and analytical determination by a HPLC-DAD method, which could be applied to quality control in routine analysis.

\section{MATERIAL AND METHODS}

\section{Chemicals and reagents}

Analytical standards of sulphadiazine (SDZ), sulphamethoxypyridazine (SPZ) and sulphamethoxazole (SMX) were obtained from Sigma-Aldrich (St. Louis, MO, USA). Acetonitrile and methanol (HPLC-grade), anhydrous magnesium sulphate, sodium acetate, analytical-grade disodium hydrogenphosphate and potassium dihydrogenphosphate were purchased from Vetec (Rio de Janeiro, RJ, BR), whereas phosphoric acid, acetic acid and the $25 \%$ ammonia solution $\left(\mathrm{NH}_{4} \mathrm{OH}\right)$ were purchased from Merck-Schuchard (Munich, Germany). The primary secondary amine (PSA)-bonded silica was supplied by Varian (Walnut Creek, CA, USA). Ultrapure water was obtained from a Milli-Q gradient water system (Millipore, Bedford, MA, USA). OASIS HLB ( $N$-vinylpyrrolidone/ divinylbenzene copolymer) $200 \mathrm{mg} / 5 \mathrm{~cm}^{3}$ cartridges (Waters, Milford, MA, USA) were used for clean-up during the development of the extraction procedure.

Stock standard solutions of individual compounds (with concentrations of $1 \mathrm{~g} \mathrm{~L}^{-1}$ ) were prepared by the exact weighing of the powder and dissolved in $10 \mathrm{~mL}$ of metha- nol for SMX and SPZ; for SDZ, the powder was dissolved in $10 \mathrm{~mL}$ of sodium hydroxide solution $\left(0.025 \mathrm{~mol} \mathrm{~L}^{-1}\right)$. Both solutions were then stored at $-20^{\circ} \mathrm{C}$ in the dark. A multicompound-working standard solution at a concentration of $20 \mu \mathrm{g} \mathrm{mL}^{-1}$ of each compound was prepared by the appropriate dilutions of the stock solutions with methanol and stored in amber glass flasks closed at $-20^{\circ} \mathrm{C}$ in the dark. This solution was stable for 4 weeks, after which it was replaced with a fresh solution. A buffer solution was prepared by dissolving $3.48 \mathrm{~g}$ of potassium dihydrogenphosphate and $1.38 \mathrm{~g}$ of disodium hydrogenphosphate in $500 \mathrm{~mL}$ of ultrapure water and diluting it to $1000 \mathrm{~mL}$. The $\mathrm{pH}$ of the phosphate buffer was adjusted to 3.5 by adding $10 \%$ phosphoric acid.

\section{Apparatus and software}

Chromatographic analyses were performed using a Shimadzu system consisting of a Model LC-10ATvp pump, a Model SIL-10AF auto injector, a Model CTO10ASvp column oven, and a Model SPD-M10Avp PDA detector. The data were analyzed with ClassVP software, taking into account the peak area of the analytes. The separation was carried out on a reverse phase octyldecylsilane C18 stainless steel column Lichrospher 60 RP, Select B, $250 \mathrm{~mm} \times 4 \mathrm{~mm}, 5 \mu \mathrm{m}$ particle size (Merck, Darmstadt, Germany), preceded by a precolumn cartridge of the same material. The chromatographic separation was carried out with a mobile phase consisting of a mixture of acetonitrile:phosphate buffer $(25: 75, \mathrm{v} / \mathrm{v})$, which was filtered through a $0.45-\mu \mathrm{m}$ nylon filter with the assistance of a Millipore ${ }^{\circledR}$ support for filtration and degassed using an ultrasonic bath (Unique, Ultracleaner) before analysis. The mobile phase was monitored at a wavelength of $265 \mathrm{~nm}$ with a flow rate of $0.5 \mathrm{~mL} \mathrm{~min}^{-1}$ for $11 \mathrm{~min}$, increasing by $1.2 \mathrm{~mL} \mathrm{~min}^{-1}$ for $17 \mathrm{~min}$, followed by a re-equilibration time of $3 \mathrm{~min}$ at a flow rate of $0.5 \mathrm{~mL} \mathrm{~min}^{-1}$, for a total run time of $20 \mathrm{~min}$ at a column oven temperature of $40^{\circ} \mathrm{C}$.

In the first step of sample preparation of the modified QuEChERS method, a high-volume centrifuge was used, while in the second step and in solid-phase extraction method, a Sigma 2-3 centrifuge was used. A Certomat (B. Braun Biotech International) vortex mixer, a $\mathrm{pH}$ meter, a combined glass electrode (Nova Técnica, São Paulo, Brazil), a Britania mixer and a Kern 410 analytical balance were also used.

\section{Sample preparation}

The chicken breast samples were diced into small pieces and then crushed in a mixer for $2 \mathrm{~min}$ at high speed; 
they were then deep-frozen until the analysis. For the construction of the analytical curves, samples of chicken breast purchased from local supermarkets were tested to verify the possible existence of the analyzed medications. The blank samples were fortified with the multicompound working standard solution.

\section{Modified QuEChERS method}

For the modified QuEChERS method, $10 \mathrm{~g}$ of crushed tissue sample was taken into a $100-\mathrm{mL}$ fortified glass centrifuge tube, and $15 \mathrm{~mL}$ of acetonitrile with $1 \%$ acetic acid was added; the mixture was vortexed for $1 \mathrm{~min}$. Afterward, $6 \mathrm{~g}$ of anhydrous magnesium sulphate and $1.5 \mathrm{~g}$ of sodium acetate were added, and the tubes were vortexed immediately for $1 \mathrm{~min}$, followed by centrifugation at 3500 rpm for $10 \mathrm{~min}$. A volume of $7 \mathrm{~mL}$ of the supernatant was taken and placed in a glass tube containing $175 \mathrm{mg}$ of PSA and $1 \mathrm{~g}$ of anhydrous magnesium sulphate. The mixture was shaken manually for $30 \mathrm{~s}$, and the tube was centrifuged for $15 \mathrm{~min}$ at $3500 \mathrm{rpm}$. Following centrifugation, a 5-mL aliquot was transferred to another tube to be evaporated to dryness under a stream of nitrogen at $40^{\circ} \mathrm{C}$. The residual was reconstituted in $1 \mathrm{~mL}$ of the mobile phase and centrifuged at $3500 \mathrm{rpm}$ for $10 \mathrm{~min}$, and $100 \mu \mathrm{L}$ was injected into the LC system.

\section{Solid-phase extraction (SPE)}

The modified procedure was based on two procedures previously employed for the determination of trimethoprim and sulphonamide residues in buffalo meat (Biswas et al., 2007) and the determination of veterinary drugs in honey (Martínez-Vidal et al., 2009). For extraction, $50 \mathrm{~g}$ of crushed chicken breast was taken into a $200 \mathrm{~mL}$ beaker, and $50 \mathrm{~mL}$ of ultrapure water was added. The mixture was homogenized for 2 min using a mixer. After that, $2 \mathrm{~g}$ of homogenate was accurately weighed in a glass tube of $15 \mathrm{~mL}$ by dispensing the homogenate with the help of a micropipette of $1000-5000 \mu \mathrm{L}$ capacity. Then, $4 \mathrm{~mL}$ of acetonitrile was added to the sample, and the tube was held for $10 \mathrm{~min}$ at room temperature, vortexed at high speed for $10 \mathrm{~min}$, and finally centrifuged at $3500 \mathrm{rpm}$ for $15 \mathrm{~min}$. A volume of $4 \mathrm{~mL}$ of supernatant was transferred to another tube to be evaporated to dryness under a stream of nitrogen at $40^{\circ} \mathrm{C}$. The residual was reconstituted in $1 \mathrm{~mL}$ of a solution of water $\mathrm{pH}$ 9.0: acetonitrile $(75: 25, \mathrm{v} / \mathrm{v})$. It was prepared daily, adjusting the $\mathrm{pH}$ of the water with a sodium hydroxide solution of 0.1 mol L-1, and then loaded into an OASIS HLB (200 mg) cartridge previously conditioned with $1 \mathrm{~mL}$ of methanol and $1 \mathrm{~mL}$ of ultrapure water. The cartridges were washed with $1 \mathrm{~mL}$ of ultrapure water and vacuum-dried for 2 min. The elution of analytes was carried out by adding sequentially $1 \mathrm{~mL}$ of methanol, $1 \mathrm{~mL}$ of acetonitrile and $1 \mathrm{~mL}$ of $0.12 \%(\mathrm{v} / \mathrm{v})$ of $25 \%$ of ammonia solution in methanol. The collected eluent was evaporate under a stream of nitrogen, redissolved in $0.5 \mathrm{~mL}$ of the mobile phase and centrifuged at $3500 \mathrm{rpm}$ for $10 \mathrm{~min}$; finally, $100 \mu \mathrm{L}$ was injected into the LC system.

\section{Method validation}

For the QuEChERS method, the validation was carried out according to internationally accepted criteria (European Commission, 2002), i.e., linearity, selectivity, limit of quantification (LOQ), limit of detection (LOD), decision limit $(\mathrm{CC} \alpha)$, detection capability $(\mathrm{CC} \beta)$, precision, recovery and accuracy. For the SPE method, the validation was carried out also according to internationally accepted criteria (European Commission, 2002), i.e., linearity, selectivity, accuracy and precision, recovery, limit of quantification (LOQ), and limit of detection (LOD). Stability and ruggedness were also evaluated.

The linearity, linear range and sensitivity were established through the analytical curve obtained by six replicates of analysis for the three analytes, using six concentration levels $\left(30,50,100,150,175\right.$, and $200 \mu \mathrm{g} \mathrm{kg}^{-1}$ for SDZ and 25, 50, 100, 150, 175, and $200 \mu \mathrm{g} \mathrm{kg}^{-1}$ for SMX and SPZ) in the chicken breast matrix. Analytical curves were constructed by plotting the peak area against the concentration of each drug; they were evaluated by least squares regression analysis. The sensitivity is the slope of the calibration graph. The interference of endogenous compounds was assessed by analyzing drug-free samples and chicken breast spiked with SDZ, SPZ and SMX.

The limit of detection (LOD) and limit of quantitation (LOQ) were determined at the signal-to-noise ratios of 3 and 10, respectively, measured at the approximate retention time of the corresponding analyte peak.

The critical concentrations for MRL compliance (CC $\alpha$, where $\alpha=0.05$ ) were calculated from the MRL value plus 1.64 times the standard deviation of the fortified samples at the MRL. The CC $\beta$ was obtained by adding $\mathrm{CC} \alpha 1.64$ times the same standard deviation.

Inter- and intra-day variability of the method was determined by analyzing six replicates of three samples of low, medium and high concentrations $(30,100$ and $200 \mu \mathrm{g} \mathrm{kg}^{-1}$ for SDZ and 25, 100 and $200 \mu \mathrm{g} \mathrm{kg}^{-1}$ for SMX and SPZ). The intra-day precision was evaluated on the same day ( $n=6 /$ each level), while the inter-day precision was evaluated on separate days $(n=6)$ using different ana- 
lysts. The results were expressed as the relative standard deviation (RSD, \%) of peak area measurements.

For the recovery and accuracy tests, SDZ, SPZ and SMX from chicken samples were measured at three levels (30, 100 and $200 \mu \mathrm{g} \mathrm{kg}^{-1}$ for SDZ and 25, 100 and $200 \mu \mathrm{g} \mathrm{kg}^{-1}$ for SMX and SPZ) prepared in six replicates. The efficiency of the extraction was calculated by comparing the peak areas of the analytes to those obtained by the analysis of spiked extracts of chicken blank samples, prepared as described above at the same concentration. For accuracy, after extraction and chromatographic analysis, the results were compared to the theoretically added values, and the results were expressed as the relative error (\%).

The SA stability was determined in the solvent (working standard solution at $20 \mu \mathrm{g} \mathrm{mL}^{-1}$ ) and in the matrix spiked at $100 \mu \mathrm{g} \mathrm{kg}^{-1}$. The stability of the stock standard solutions in methanol was analyzed for one month, and the instrumental responses were compared to the peak areas obtained at the moment of solution preparation. The chemical stability of the analytes in chicken samples was tested in the following conditions: sitting at room temperature for $8 \mathrm{~h}$ (bench-top stability), stored at $-20{ }^{\circ} \mathrm{C}$ and exposed to three freeze-thaw cycles. The extracts were tested for $24 \mathrm{~h}$ (auto-sampler stability). For comparison, all the stability determinations were assessed by preparing a set of freshly made samples. The analytes were considered stable if the variation of the concentrations between the assays were less than $15 \%$ of initial time response.

The method ruggedness was estimated for minor changes by means of the Youden robustness test. Three different factors, such as mobile phase $\mathrm{pH}$ (3.3 and 3.5), organic solvent in mobile phase ( 25 and $30 \%$ ) and column temperature $\left(35\right.$ and $40{ }^{\circ} \mathrm{C}$ ) were chosen for the entire analytical chromatographic conditions because of their possible critical influence.

\section{RESULTS AND DISCUSSION}

To ensure food safety, it is necessary to develop selective, sensitive, easy and inexpensive analytical methods that comply with current legislation, allow the routine, simultaneous determination of several compounds of veterinary drugs and provide accurate quantitative data. In this study, a QuEchERS technique for the determination of SAs in chicken breast samples has been developed and compared with a traditional SPE technique, using a $\mathrm{N}$ vinylpyrrolidone/divinylbenzene copolymer as a sorbent.

\section{Chromatographic optimized conditions}

We chose to use a flow ramp to provide an effective separation of the analytes with a lower consumption of organic solvents, instead of using an increase of these solvents in the mobile phase. According to the UV spectrum, 265-270 nm was the absorbance maximum of the analyzed SAs. The use of the buffer with $\mathrm{pH} 3.5$ in the mobile phase maintained the efficiency of the separation of the compounds $\left(\mathrm{p} K_{\mathrm{a} 1}\right.$ between 1.4 and 2.2 values and $\mathrm{p} K_{\mathrm{a} 2}$ between 5.8 and 7.2 values), allowing greater interaction with the stationary phase by van der Waals forces. No interference was observed in the analytes' retention time, which was established as 10.1 minutes for SDZ, 12.7 minutes for SPZ and 16.5 minutes for SMX.

In order to verify the system suitability the theoretical plates $(\mathrm{N})$ were calculated for the chromatographic column to evaluate the number of separate layers, the tailing factor $(\mathrm{T})$ was a measure of the peak tailing, the resolution (Rs) described how well the species were separated, and the retention factor $(\mathrm{k})$ was used to describe the migration rate of analytes on a column. The system was suitable, as the results of the test were considered satisfactory (US FDA 1994), according to Table I.

The European Commission Decision 2002/657/EC (European Commission, 2002) mentions that the absorption maxima in the spectrum of the analyte shall be at the same wavelengths as those of the calibration standard within a margin determined by the resolution of the detection system. For diode array detection, this is typically within $\pm 2 \mathrm{~nm}$. In our study, no differences were observed between the wavelength of maximum absorption of the extract and the calibration standards for the SMX $(268 \mathrm{~nm})$ and SPZ (264 nm), while for the SDZ the wavelength

TABLE I - System suitability parameters to developed method to simultaneous analysis of sulphonamides in chicken breast samples

\begin{tabular}{lccccc}
\hline Analyte $^{\mathrm{a}}$ & Retention time & Number of plates (N) & Resolution $^{\mathrm{b}}(\mathrm{Rs})$ & Tailing factor (TF) & Retention factor (k) \\
\hline$S D Z$ & 10.1 & 6248 & - & 1.04 & 9.12 \\
$S P Z$ & 12.7 & 31744 & 3.22 & 1.00 & 11.68 \\
$S M X$ & 16.5 & 38966 & 6.22 & 0.89 & 15.54 \\
\hline
\end{tabular}

${ }^{a}$ Sulphadiazine (SDZ) sulphamethoxypyridazine (SPZ) and sulphamethoxazole (SMX); ${ }^{b}$ Resolution was calculated between: sulphamethoxypyridazine and sulphadiazine; sulphamethoxazole and sulphamethoxypyridazine 
of maximum absorption for the extract was $266 \mathrm{~nm}$ and for the standard was $268 \mathrm{~nm}$. Moreover, in the observed points, the difference between the two spectra should not exceed $10 \%$ of the absorbance of the calibration standard. The similarity indexes were 0.9708 (SMX), 0.9706 (SPZ) and 0.9697 (SDZ), obtained when compared samples extracted by the method QuEChERS with the calibration standards at a concentration of $100 \mu \mathrm{g} \mathrm{kg}^{-1}$.

Regarding robustness, the application of the Youden test consisted of the introduction of minor simultaneous changes in possible critical factors, which were chosen in the developed method according to an established experimental design with the aim of identifying the critical factors that should be controlled to obtain accurate assay results. The standard deviation of the differences between two levels of each factor was then calculated, and the results obtained demonstrated that only the variation in the $\%$ of organic solvent in the mobile phase affected the results.

\section{Development of QuEChERS method}

Traditional sample preparation for SAs in animal tissues involves isolation with an organic solvent (e.g., methanol, acetonitrile, ethyl acetate), followed by SPE with polar, non-polar or ion-exchange sorbent materials (Posyniak, Zmudzki, Mitrowska, 2005). Sergi et al. (2007) presented for sulphonamides (SAs) in animal tissues (raw meat and meat-based baby food), based on matrix solid phase dispersion (MSPD). The authors discussed that in complex matrices extraction is usually the critical step of analysis: several procedures were employed for the recovery of SAs in animal tissues, but often they entail time and solvent-consuming processes. MSPD has demonstrated itself to be a very efficient extraction technique for matrices such as animal tissues, with simplified and shortened procedures, and very low solvent consumption. The procedure allowed to obtain quantitative recovery, high selectivity improved by a cool eluant, and easy application. Good recoveries are accompanied by low RSDs and not a significative matrix effect. Frenich et al. (2010) published a comparison of several techniques for veterinary drugs in eggs. QuEChERS procedure was simpler and faster, but extracted fewer compounds than solvent extraction. Pulido et al. (2011) evaluated the several techniques to determinate sulphas residues in shrimps. Different methods of extraction and cleaning were tested based on a partitioning of the analytes. Of the tested procedures, the QuEChERS showed better results in terms of recovery and lower interference from matrix constituents.

In Figure 1, the original (unbuffered) (Anastassiades et al., 2003) and the buffered (Lehotay, Mastovska, Lightfield, 2005) QuEchERS methodologies applied in the present study can be compared. The buffered methodology with acetonitrile could be highly suitable for the extraction of SAs evaluated from chicken breast, as this solvent can precipitate proteins. After the addition of magnesium sulfate and buffering salts ( $\mathrm{pH} 5-5.5$ ), the mixture is shaken intensively and centrifuged for phase separation. An aliquot of the organic phase is cleaned up by dispersive SPE employing bulk sorbent (PSA) and $\mathrm{MgSO}_{4}$ for the removal of residual water. The final extract can be directly employed for HPLC analysis. In the present study, the dryness step was evaluated, and it provides an increment of the recovery of the analytes (Figure 1).
(A)

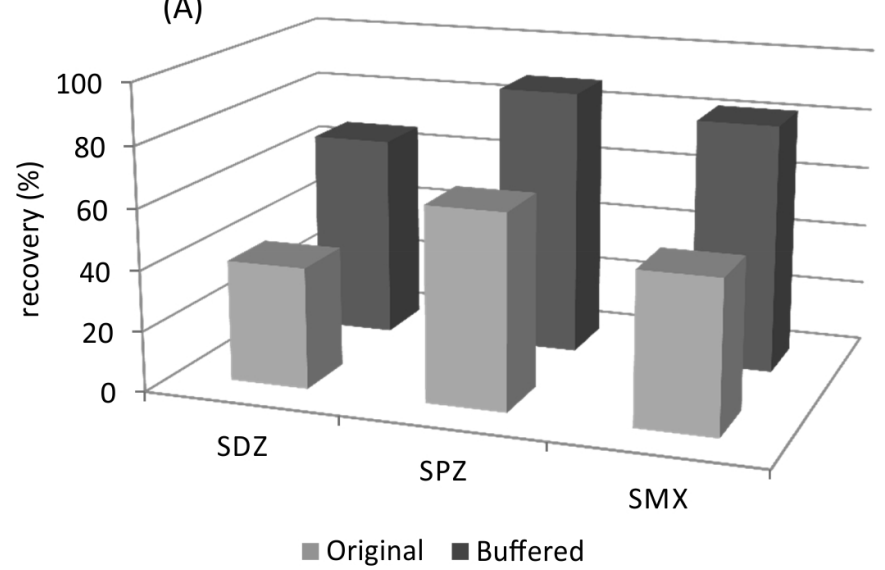

(B)

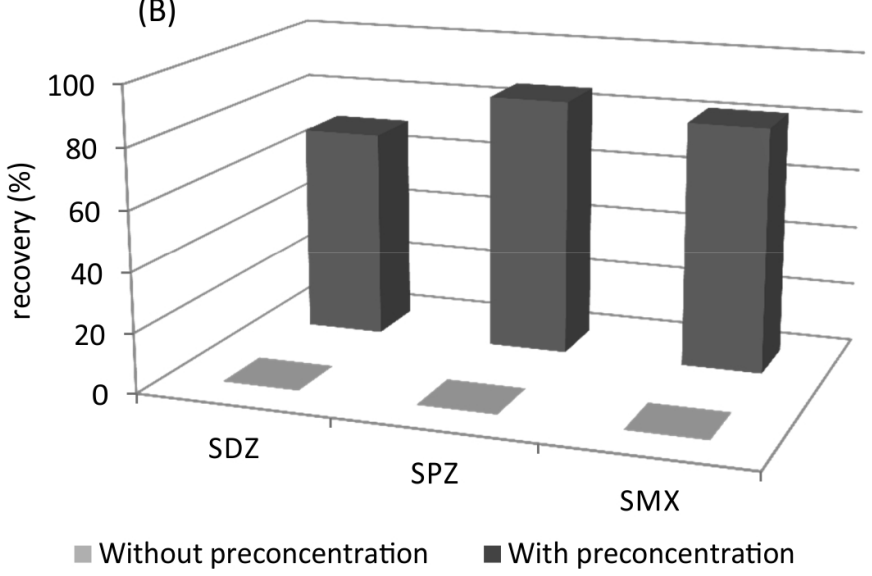

FIGURE 1 - (A) Comparison of the original and buffered QuEChERS method in the recovery of sulphonamides. (B) Effect of preconcentration step in the QuEChERS method. Sulphadiazine (SDZ), sulphamethoxypyridazine (SPZ) and sulphamethoxazole (SMX) at concentrations levels of $100 \mu \mathrm{g} \mathrm{kg}^{-1}$. 
In view of these results, the step was included in the methodology, and the results of this parameter are presented in Tables II and III.

The method was linear in the range evaluated for SAs in chicken breast samples (Table II). The linear range established is satisfactory; it is able to quantify the residue values $\left(100 \mu \mathrm{g} \mathrm{kg}^{-1}\right)$ in accordance with the European Community and the Brazilian Agricultural Ministry (European Commission, 2002; MAPA, 2009). In addition, the deviation of the individual points from the calibration curves was always lower than $20 \%$.
The matrix effect was also evaluated. Because the presence of matrix components can affect the analysis and the selectivity, the influence must be studied. For this purpose, the concentrations were analyzed in pure solvent and in extracted blank chicken samples, and the slopes of the calibration curves were compared based on a t-test that revealed they were not statistically different ( $p$-value higher than 5\%). The selectivity was evaluated by the blank-sample analysis, and the chromatograms are shown in Figure 2.

The analytical method is apt and sensitive enough to carry out residue analysis for the SAs studied, as the LOD

TABLE II - Linear regression data for sulphadiazine (SDZ), sulfametoxypyridazine (SPZ) and sulphamethoxazole (SMX) limits of detection (LOD) and quantification (LOQ), in chicken breast samples analysed by QuEChERS-HPLC-DAD proposed method

\begin{tabular}{lcccccc}
\hline Compound & $\begin{array}{c}\text { Linear range } \\
(\mu \mathrm{g} \mathrm{kg}-1\end{array}$ & slope & intercept & $\mathrm{r}^{2}$ value & $\begin{array}{c}\text { LOQ } \\
\left(\mu \mathrm{kg}^{-1}\right)\end{array}$ & $\begin{array}{c}\text { LOD } \\
\left(\mu \mathrm{kg}^{-1}\right)\end{array}$ \\
\hline SDZ & $30-200$ & 688.42 & -3185.3 & 0.9929 & 30 & 13 \\
SPZ & $25-200$ & 351.51 & 4446.7 & 0.9924 & 25 & 10 \\
SMX & $25-200$ & 332.19 & -6304.6 & 0.9936 & 25 & 10 \\
\hline
\end{tabular}

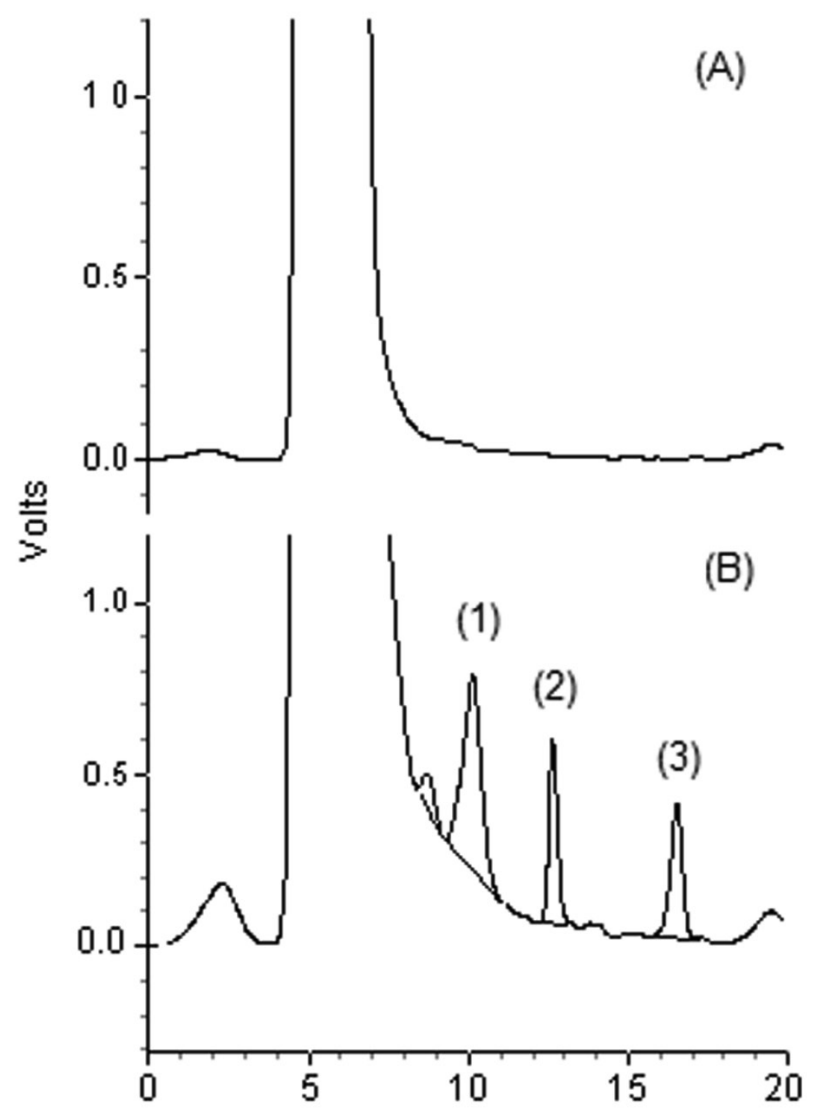

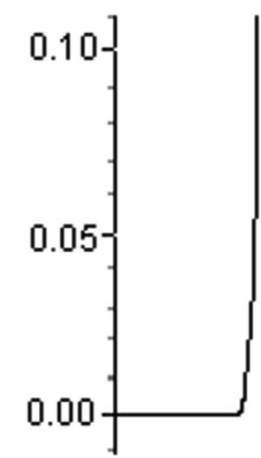

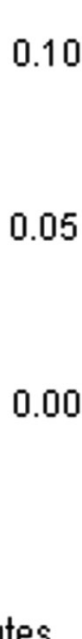

(C)

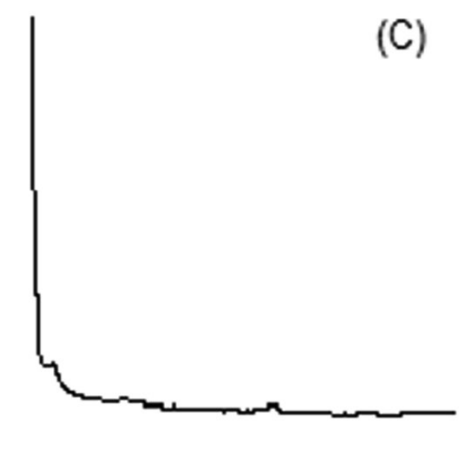

(2)

(D)

(1)

(3)
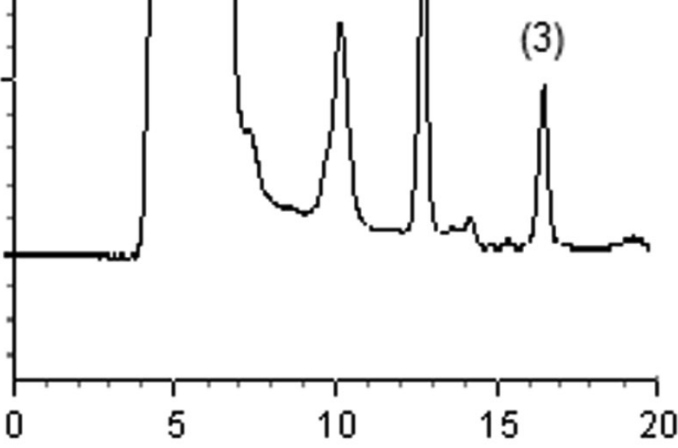

\section{Minutes}

FIGURE 2 - Chromatograms of QuEChERS method: (A) blank chicken sample; (B) blank chicken sample fortified at $100 \mu \mathrm{g} \mathrm{kg}^{-1}$. Chromatograms of SPE method (C) blank chicken sample and (D) blank chicken sample fortified at $100 \mu \mathrm{g} \mathrm{kg}^{-1}$. All analysis was performed in the chromatographic conditions optimized. 
and LOQ values are ten and three times, respectively, lower than the MRLs (European Commission, 2002; MAPA, 2009). Furthermore, if were added the LODs of the three analytes, the mean value is still below the MRLs, which enables the method to the analysis of the three analytes, even if they are found in the same sample, whereas the MRL for sulphonamides refers to the sum of residues of drugs of this group.

Tests of inter- and intra-assay precision produced relative standard deviations (RSD) acceptable (Table III) according to the European Community (European Commission, 2002), which recommends values below $15 \%$, except for the LQ, which must be less than or equal to $20 \%$. Accuracy can also be verified in Table III. To evaluate the validity of the proposed method, the test was carried out at three levels, and the results can be considered satisfactory. According to the concept of the European Commission Decision 2002/657/EC (European Commission, 2002), the $\mathrm{CC} \alpha$ (decision limit) and $\mathrm{CC} \beta$ (detection capability) have been estimated in this case for permitted veterinary drug substances. The values are presented in Table III. With an MRL set at $100 \mu \mathrm{g} \mathrm{kg}^{-1}, \mathrm{CC} \alpha$ and CC $\beta$ were always lower than $115 \mu \mathrm{g} \mathrm{kg}^{-1}$.

\section{Comparison of the proposed QuEChERS method and the SPE}

To compare the results obtained with the QuEChERS method, the SPE method was optimized in the laboratory. The modified procedure was based on two procedures previously employed for the determination of SAs in buffalo meat (Biswas et al., 2007) and in honey (Martínez-Vidal et al., 2009). Several solvents were tested for the conditioning, washing and elution steps. For an acceptable recovery, the sorbent was previously conditioned with methanol and ultrapure water and washed with ultrapure water. The analytes were then eluted by adding sequentially methanol, acetonitrile and $0.12 \%(\mathrm{v} / \mathrm{v})$ of $25 \%$ of ammonia solution in methanol.

The linearity is demonstrated in Table IV, and the SPE procedure was sensitive enough to carry out the residue analysis for the SAs studied, as the LOD and LOQ values were lower than the MRLs (European Commission, 2002; MAPA, 2009).

Tests of repeatability, recovery and accuracy of the produced results, employing the SPE methodology, are acceptable according to the European Community (Euro-

TABLE III - Intraday and interday precision, accuracy, recovery, decision limit (CC $\alpha)$ and detection capability (CC $\beta)$ for sulphadiazine (SDZ), sulfametoxypyridazine (SPZ) and sulphamethoxazole (SMX) in chicken breast samples analysed by QuEChERS-HPLCDAD proposed method

\begin{tabular}{lccc}
\hline Parameter & SDZ & SPZ & SMX \\
\hline Intraday precision (RSD, \%) & & & \\
$30 \mu \mathrm{g} \mathrm{kg}^{-1}$ & 3.56 & 9.03 & 10.90 \\
$100 \mu \mathrm{g} \mathrm{kg}^{-1}$ & 10.84 & 6.97 & 8.57 \\
$200 \mu \mathrm{g} \mathrm{kg}^{-1}$ & 8.56 & 14.09 & 1.90 \\
\hline Interday precision (RSD, \%) & & & 10.19 \\
$30 \mu \mathrm{g} \mathrm{kg}^{-1}$ & 9.65 & 2.50 & 2.44 \\
$100 \mu \mathrm{g} \mathrm{kg}^{-1}$ & 6.48 & 1.68 & 2.07 \\
$200 \mu \mathrm{g} \mathrm{kg}^{-1}$ & 1.53 & 4.07 & \\
\hline Accuracy (bias, \%) ${ }^{\mathrm{a}}($ relative error, \%) & & $+11.87(8.03)$ \\
$30 \mu \mathrm{g} \mathrm{kg}^{-1}$ & $-8.57(9.12)$ & $+11.48(2.95)$ & $-5.59(2.23)$ \\
$100 \mu \mathrm{g} \mathrm{kg}^{-1}$ & $+2.08(6.40)$ & $+6.24(1.74)$ & $+9.46(2.01)$ \\
$200 \mu \mathrm{g} \mathrm{kg}^{-1}$ & $+7.86(1.52)$ & $-4.55(4.17)$ & 88.5 \\
\hline Recovery (\%) & & & 75.2 \\
$30 \mu \mathrm{g} \mathrm{kg}^{-1}$ & 74.5 & 95.8 & 88.6 \\
$100 \mu \mathrm{g} \mathrm{kg}^{-1}$ & 94.2 & 87.5 & 110.6 \\
$200 \mu \mathrm{g} \mathrm{kg}^{-1}$ & 98.7 & 85.7 & 114.8 \\
\hline $\mathrm{CC} \alpha\left(\mu \mathrm{g} \mathrm{kg}^{-1}\right)$ & 104.7 & 103.3 & \\
$\mathrm{CC} \beta\left(\mu \mathrm{g} \mathrm{kg}^{-1}\right)$ & 108.4 & 105.7 & \\
\hline
\end{tabular}

${ }^{a}$ Relative standard deviation is given in brackets $(n=6 /$ each level) 
TABLE IV - Linear regression data for sulphadiazine (SDZ), sulfametoxypyridazine (SPZ) and sulphamethoxazole (SMX) limits of detection (LOD) and quantification (LOQ), in chicken breast samples analysed by SPE-HPLC-DAD method

\begin{tabular}{|c|c|c|c|c|c|c|}
\hline \multirow{2}{*}{ Compound } & \multirow{2}{*}{$\begin{array}{l}\text { Linear range } \\
\qquad\left(\mu \mathrm{g} \mathrm{kg}^{-1}\right)\end{array}$} & \multirow{2}{*}{ slope } & \multicolumn{2}{|c|}{ Regression line } & \multirow{2}{*}{$\begin{array}{c}\mathrm{LOQ} \\
\left(\mu \mathrm{g} \mathrm{kg}^{-1}\right)\end{array}$} & \multirow{2}{*}{$\begin{array}{c}\mathrm{LOD} \\
\left(\mu \mathrm{g} \mathrm{kg}^{-1}\right)\end{array}$} \\
\hline & & & intercept & $\mathrm{r}^{2}$ value & & \\
\hline$\overline{\mathrm{SDZ}}$ & $15-200$ & 4146.5 & 618.08 & 0.9977 & 15 & 5 \\
\hline SPZ & $15-200$ & 169.22 & 563.14 & 0.9987 & 15 & 5 \\
\hline SMX & $15-200$ & 636.04 & 320.76 & 0.9965 & 15 & 5 \\
\hline
\end{tabular}

TABLE V - Intraday precision, accuracy and recovery for sulphadiazine (SDZ), sulfametoxypyridazine (SPZ) and sulphamethoxazole (SMX) in chicken breast samples extracted by SPE-HPLC-DAD

\begin{tabular}{lccc}
\hline Parameter & SDZ & SPZ & SMX \\
\hline Intraday precision (RSD, \%) & & & \\
$30 \mu \mathrm{g} \mathrm{k}^{-1}$ & 8.87 & 8.18 & 11.90 \\
$100 \mu \mathrm{g} \mathrm{kg}^{-1}$ & 5.50 & 1.50 & 14.51 \\
$200 \mu \mathrm{g} \mathrm{kg}^{-1}$ & 8.33 & 10.73 & 11.15 \\
\hline Accuracy (bias, \%) ${ }^{\text {a }}$ (relative error, \%) & & & \\
$30 \mu \mathrm{g} \mathrm{kg}^{-1}$ & $-9.89(7,55)$ & $+4.25(8,23)$ & $+0.34(12,37)$ \\
$100 \mu \mathrm{g} \mathrm{kg}^{-1}$ & $+0.66(5,32)$ & $-0.14(1,50)$ & $+1.18(14,65)$ \\
$200 \mu \mathrm{g} \mathrm{kg}^{-1}$ & $+1.88(8,24)$ & $+1.16(10,74)$ & $+0.69(11,18)$ \\
\hline Recovery & & & 63.42 \\
$30 \mu \mathrm{g} \mathrm{kg}^{-1}$ & 57.39 & 69.75 & 66.46 \\
$100 \mu \mathrm{g} \mathrm{kg}^{-1}$ & 69.60 & 73.07 & 70.90 \\
$200 \mu \mathrm{g} \mathrm{kg}^{-1}$ & 63.42 & 66.46 & \\
\hline
\end{tabular}

${ }^{\text {a }}$ Relative standard deviation is given in brackets $(\mathrm{n}=6 /$ each level)

pean Commission, 2002). Observing the Table V, for most of the compounds and concentrations assayed, recoveries are lower than $70 \%$. This is also another point to select QuEChERS procedure instead of SPE.

When the extraction methods were compared in terms of the initial amount of sample and final concentration in the elution solvent, it can be noted that SPE provided a concentration approximately 60 times higher than the QuEChERS methodology, indicating that solidphase extraction introduces low amounts of matrix in the chromatographic system and the effect of matrix can be minimized, with a better resolution between the SDZ peak and the interferents peaks (Figure 2). However, the procedure is tedious and time consuming (6 samples/ hour). Nevertheless, QuEChERS is a fast and inexpensive procedure, and the evaporation of the solvent permitted the concentration of the analytes in the extract with higher analytical frequency (12 samples/hour). Though the SPE method produced low values of detection and quantitation limits, by employing QuEChERS, the limits are satisfactory for the application of residue monitoring of SAs.
To evaluate the stability, freeze-thaw cycles and storage at room temperature for $8 \mathrm{~h}$ (bench-top stability), tests were performed, and the analytes remained stable in the samples. In the extracted samples, the analytes remained stable for $24 \mathrm{~h}$ in the equipment auto-sampler. A $20 \mu \mathrm{g} \mathrm{mL}^{-1}$ solution stored at $-20^{\circ} \mathrm{C}$ remained stable for one month. The analytes were considered stable in the condition evaluated if the variation in the concentrations was less than $15 \%$ of initial time response.

To evaluate the applicability of the proposed QuEChERS method, six samples from different brands and supermarkets from Alfenas (Brazil) were analyzed $(n=3 /$ sample). The samples were also analyzed by the SPE methodology. In both methods, none of the samples showed contamination of the SAs studied at detectable levels.

\section{CONCLUSIONS}

A QuEChERS-HPLC-DAD method has been proposed for the simultaneous determination of sulpha 
compounds: sulphadiazine, sulphametoxipiridazine and sulphamethoxazole. QuEchERS is inexpensive, fast and easy, and the extraction of the analytes of the matrix was successfully employed in chicken breast samples. In addition, the method presented linearity, precision, selectivity and sensitivity. Therefore, the validated method is clearly useful for the practical residue monitoring of the drugs evaluated in chicken samples, as all the values were within the acceptable criteria used for food safety.

\section{ACKNOWLEDGEMENTS}

This research was supported by the Conselho Nacional de Desenvolvimento Científico e Tecnológico (CNPq)/Brazil, Capes/ Brazil and by Fundação de Amparo à Pesquisa do Estado de Minas Gerais (FAPEMIG)/ Brazil (processes number CDS-APQ-4487-4.04/07 and CDS-PPM-00055-09).

\section{REFERENCES}

ANASTASSIADES, M.; LEHOTAY, S.J.; STAJNBAHER, D.; SCHENK, F.J. Fast and easy multiresidue method employing acetonitrile extraction/partitioning and "dispersive solid-phase extraction" for the determination of pesticides residues in produce. J. AOAC Int., v.86, p.412431, n.2, 2003.

BEDOR, D.C.G; GONÇALVES, T.M.; FERREIRA, M.L.L.; DE SOUSA, C.E.M.; MENEZES, A.L.; OLIVEIRA, E.J.; DE SANTANA, D.P. Simultaneous determination of sulfamethoxazole and trimethoprim in biological fluids for high-throughput analysis: Comparison of HPLC with ultraviolet and tandem mass spectrometric detection. $J$. Chromatogr. B, v.863, n.1, p.46-54, 2008.

BISWAS, A.K.; RAO, G.S.; KONDAIAH, N.; ANJANEYULU, A.S.R.; MALIK, J.K. Simple multiresidue method for monitoring of trimethoprim and sulphonamide residues in buffalo meat by high-performance liquid chromatography. J. Agric. Food Chem., v.55, n.22, p.8845-8850, 2007.

BOGIALLI, S.; CURINI, R.; DI CORCIA, A.; NAZZARI, M.; POLCI, M.L. Rapid confirmatory assay for determining 12 sulfonamide antimicrobials in milk and eggs by matrix solid-phase dispersion and liquid chromatography-mass spectrometry. J. Agric. Food Chem., v.51, n.15, p.42254232, 2003.
BOGIALLI, S.; DI CORCIA, A. Recent applications of liquid chromatography-mass spectrometry to residue analysis of antimicrobials in food of animal origin. Anal. Bioanal. Chem., v.395, n.4, p.947-966, 2009.

CHIAOCHAN, C.; KOESUKWIWAT, U.; YUDTHAVORASIT, S.; LEEPIPATPIBOON, N. Efficient hydrophilic interaction liquid chromatography-tandem mass spectrometry for the multiclass analysis of veterinary drugs in chicken muscle. Anal. Chim. Acta, v.682, n.1-2, p.117-129, 2010.

CHICO, J.; RÚBIES, A.; CENTRICH, F.; COMPANYÓ, R.; PRAT, M.D.; GRANADOS, M. High throughput multiclass method for antibiotic residue analysis by liquid chromatography-tandem mass spectrometry. $J$. Chromatogr. A, v.1213, n.2, p.189-199, 2008.

CHRISTODOULOU, E.A.; SAMANIDOU, V.F.; PAPADOYANNIS, I.N. Development and validation of an HPLC confirmatory method for residue analysis of ten quinolones in tissues of various food-producing animals, according to the European Union Decision 2002/657/EC. J. Sep. Sci., v.30, n.16, p.2676-2686, 2007.

CHU, Q.; ZHANG. D.; WANG, J.; YE, J. Multi-residue analysis of sulfonamides in animal tissues by capillary zone electrophoresis with electrochemical detection. J. Food Agric., v.89, n.14, p.2498-2504, 2009.

COSTI, E.M.; SICILIA, M.D.; RUBIO, S. Multiresidue analysis of sulfonamides in meat by supramolecular solvent microextraction, liquid chromatography and fluorescence detection and method validation according to the 2002/657/ EC decision. J. Chromatogr. A, v.1217, n.40, p.6250-6257, 2010.

EUROPEAN COMMISSION. Regulation 2002/657/EC, of 12th August. Implementing council directive 96/23/EC concerning the performance of analytical methods and the interpretation of the results. Official Journal of European Communities, L221/8-L221/36, 2002.

EUROPEAN COMMISSION. Regulation (EC) 470/2009 of the European Parliament and of the Council of 6 May 2009 laying down Community procedures for the establishment of residue limits of pharmacologically active substances in foodstuffs of animal origin, repealing Council Regulation (EEC) 2377/90 and amending Directive 2001/82/EC of the European Parliament and of the Council and Regulation (EC) 726/2004 of the European Parliament and of the Council. Official Journal of European Communities, L152, p.11-22, 2009a. 
EUROPEAN COMMISSION. Commission Regulation (EU) 37/2010 of 22 December 2009 on pharmacologically active substances and their classification regarding maximum residue limits in foodstuffs of animal origin. Official Journal of European Communities, L15, p.1-72, 2009 b.

FRENICH, A.G.; AGUILERA-LUIZ, M.M.; VIDAL, J.L.M.; ROMERO-GONZÁLEZ, R. Comparison of several extraction techniques for multiclass analysis of veterinary drugs in eggs using ultra-high pressure liquid chromatography-tandem mass spectrometry. Anal. Chim. Acta, v.661, n.2, p.150-160, 2010.

GAMBA, V.; TERZANO, C.; FIORONI, L.; MORETTI, S.; DUSI, G.; GALARINIC, R. Development and validation of a confirmatory method for the determination of sulphonamides in milk by liquid chromatography with diode array detection. Anal. Chim. Acta, v.637, n.1-2, p1823, 2009.

GARCÍA-MAYOR, M.A.; GARCINUÑO, R.M.; FERNÁNDEZ-HERNANDO, P.; DURAND-ALEGRÍA, J.S. Liquid chromatography-UV diode-array detection method for multi-residue determination of macrolide antibiotics in sheep's Milk. J. Chromatogr. A, v.1122, n.1-2, p.76-83, 2006.

HALLER, M.Y.; MÜLLER, S.R.; MCARDELL, C.S.; ALDER, A.C.; SUTER, M.J.-F. Quantification of veterinary antibiotics (sulfonamides and trimethoprim) in animal manure by liquid chromatography-mass spectrometry. $J$. Chromatogr. A, v.952, n.1, p.111-120, 2002.

KISHIDA, K.; FURUSAWA, N. Matrix solid-phase dispersion extraction and high- performance liquid chromatographic determination of residual sulfonamides in chicken. $J$. Chromatogr. A, v.937, n.1-2, p.49-55, 2001.

KNECHT, B.G.; STRASSER, A.; DIETRICH, R.; MÄRTLBAUER, E.; NIESSNER, R.; WELLER, M.G. Automated microarray system for the simultaneous detection of antibiotics in milk. Anal. Chem., v.76, n.3, p.646-654, 2004.

KOESUKWIWAT, U.; JAYANTA, S.; LEEPIPATPIBOON, N. Solid-phase extraction for multiresidue determination of sulfonamides, tetracyclines, and pyrimethamine in Bovine's milk. J. Chromatogr. A, v.1149, n.1, p.102-111, 2007.
KOWALSKI, P.; PLENIS, A.; OLĘDZKA, I.; KONIECZNA, L. Optimization and validation of the micellar electrokinetic capillary chromatographic method for simultaneous determination of sulfonamide and amphenicol-type drugs in poultry tissue. J. Pharm. Biomed. Anal., v.54, n.1, p.160167, 2011.

LAMAR, J.; PETZ, M. Development of a receptor-based microplate assay for the detection of beta-lactam antibiotics in different food matrices. Anal. Chim. Acta, v.586, n.1-2, p.296-303, 2007.

LEHOTAY, S.J.; MASTOVSKA, K.; LIGHTFIELD, A.R. Use of buffering and other means to improve results of problematic pesticides in a fast and easy method for residue analysis of fruits and vegetables. J. AOAC Int., v.88, n.2, p.615-629, 2005.

LU, K.H.; CHEN, C.Y.; LEE, M.R. Trace determination of sulfonamides residues in meat with a combination of solidphase microextraction and liquid chromatography-mass spectrometry. Talanta, v.72, n.3, p.1082-1087, 2007.

MAMANI, M.C.V.; REYES, F.G.R.; RATH, S. Multiresidue determination of tetracyclines, sulphonamides and chloramphenicol in bovine milk using HPLC-DAD. Food Chem., v.117, n.3, p.545-552, 2009.

MAPA, Ministério da Agricultura, Pecuária e Abastecimento do Brasil. Instrução Normativa n.14, de 25 de maio de 2009 - Aprova o Programa para Controle de Resíduos e Contaminantes em Carnes (Bovina, Aves, Suína e Equina), Leite, Mel, Ovos e Pescado. Diário Oficial da União, 28/05/2009, Seção 1, p.28, 2009.

MARTÍNEZ-VIDAL, J.L.; AGUILERA-LUIZ, M.M.; ROMERO-GONZÁLEZ, R.; GARRIDO-FRENICH, A. Multiclass analysis of antibiotic residues in honey by ultraperformance liquid chromatography-tandem mass spectrometry. J. Agric. Food Chem., v.57, n.5, p.17601767, 2009.

PECORELLI, I.; BIBI, R.; FIORONI, L.; GALARINI, R. Validation of a confirmatory method for the determination of sulphonamides in muscle according to the European Union regulation 2002/657/EC. J. Chromatogr. A, v.1032, n.1-2, p.23-29, 2004. 
POSYNIAK, A.; ZMUDZKI, J.; MITROWSKA, K. Dispersive solid-phase extraction for the determination of sulfonamides in chicken muscle by liquid chromatography. J. Chromatogr. $A$, v.1087, n.1-2, p.259-264, 2005.

PULIDO, M. V.; LÓPEZ, B. G.; REYES, J. F. G.; MARTOS, N. R.; DÍAZ, A. M. Multiclass detection and quantitation of antibiotics and veterinary drugs in shrimps by fast liquid chromatography time-of-flight mass spectrometry. Talanta, v.85, n.3, p.1419-1427, 2011.

SERGI, M.; GENTILI, A.; PERRET, D.; MARCHESE, S.; MATERAZZI, S.; CURINI, R. MSPD extraction of sulphonamides from meat followed by LC tandem MS determination. Chromatographia, v.65, n.11-12, p.757$761,2007$.

SHERIDAN, R.; POLICASTRO, B.; THOMAS, S.; RICE, D. Analysis and occurrence of 14 sulfonamide antibacterials and chloramphenicol in honey by solid-phase extraction followed by LC/MS/MS analysis. J. Agric. Food Chem., v.56, n.10, p.3509-3516, 2008.

SOTO-CHINCHILLA, J.J.; GARCÍA-CAMPAÑA, A.M.; GAMIZ-GRACIA, L. Analytical methods for multiresidue determination of sulphonamides and trimethoprim in meat and ground water samples by CE-MS and CE-MS/MS. Electrophoresis, v.28, n.22, p.4164-4172, 2007.
STUBBINGS, G.; BIGWOOD, T. The development and validation of a multiclass liquid chromatography tandem mass spectrometry (LC-MS/MS) procedure for the determination of veterinary drug residues in animal tissue using a QuEChERS (QUick, Easy, CHeap, Effective, Rugged and Safe) approach. Anal. Chim. Acta, v.637, n.12, p.68-78, 2009.

TSAI, W.; CHUANG, H.; CHEN, H.; WU, Y.; CHENG, S.; HUANG, T. Application of sugaring-out extraction for the determination of sulfonamides in honey by highperformance liquid chromatography with fluorescence detection. J. Chromatogr. A, v.1217, n.49, p.7812-7815, 2010.

U.S. DEPARTMENT OF AGRICULTURE, AGRICULTURAL RESEARCH SERVICE. 2009. USDA National Nutrient Database for Standard Reference, Release 22, Nutrient Data Laboratory. Available at: http://www.ars.usda.gov/ba/bhnrc/ ndl. Accessed on: $16^{\text {th }} \mathrm{dec} .2010$.

US FDA - United States Food and Drug Administration. Guidance for Industry. Validation of Chromatographic Methods, 1994.

Received for publication on $15^{\text {th }}$ August 2012 Accepted for publication on $03^{\text {rd }}$ January 2013 